\title{
THE IMPACT OF THE CRISES AND THE STRONG ECONOMIC SLOWDOWN ON THE PRICES OF STEEL PRODUCTS IMPORTED TO AND EXPORTED FROM POLAND
}

\author{
Bożena GAJDZIK \\ Silesian University of Technology, Gliwice, Poland, EU, bozena.gajdzik@polsl.pl
}

https://doi.org/10.37904/metal.2021.4274

\begin{abstract}
The paper presents the results of the analysis of prices of exported and imported steel products in total in Poland. Changes in prices of steel products were analyzed in the period from 2005 to 2020 . The adopted long period of analysis of steel products prices allowed to determine their level in the period before, the first in the century, the world financial crisis of 2008 and after this crisis until 2020, when the COVID-19 crisis started (and is still ongoing). The aim of the study was to answer the question about the impact of the global economic crises (economic downturn, strong economic slowdown in the world) on the level of prices of steel products imported to Poland and exported from Poland. The steel industry in Poland was used as a case.
\end{abstract}

Keywords: Steel products, prices, imports, exports, crisis

\section{INTRODUCTION}

Crises and economic downturns are hitting the foundations of growth. They disturb the social and economic order, slow down production, disturb the functioning of markets, and worsen the financial situation of enterprises. It is impossible to prevent all types of crises and be effectively prepared for their outbreak despite the implementation of crisis management - designing and applying prevention aimed at preventing the outbreak of crises [1-2]. At the end of the first decade of this century, the world was grappling with the effects of the financial crisis. At the end of the second decade, the COVID-19 crisis emerges. 2020 is known as the pandemic year. It is widely recognized that the 2008 crisis was caused by a very intensive lending activity on the market of mortgage loans granted by banks (mainly investment ones) to people with insufficient financial capabilities (subprime mortgage) [3]. The effects of the crisis reached world, Europe and Poland in 2009. In the analyzed sector, a significant drop in steel production was recorded. In 2009, crude steel production was 1,239 million tonnes compared to 1,343 million tonnes (Mt) in 2008 [4]. In 2009, EU steel production was 138.779 million tonnes (Mt), and in 2008, total production of crude steel was 197.965 million tonnes (Mt) [5]. In 2009, 7.128 million tonnes (Mt) of crude steel was produced in Poland, a 2.6 million tonnes decrease compared to 2008 [5]. During the following years, steel production is subject to more or less major economic fluctuations. Another sharp decline in production was recorded in 2019 and 2020. Global world crude steel production although reached 1,864 million tonnes (Mt) for the year 2020, down by $0.9 \%$ compared to 2019 [67]. Throughout 2020, the European Union (with the UNITED Kingdom) recorded production of 138.8 million tonnes, a decrease of $12 \%$ from the previous year [8-9]. In 2019, 8.996 million tonnes (Mt) was produced in Poland, and in 2020, 7.851 million tonnes (Mt) [10]. For comparison, in 2017-2018, the annual steel production in Poland was over 10 million tonnes (Mt) [10]. In the period from 2005 to 2019 adopted for the study, an analysis of prices of steel products (PLN/tonne) in Poland was performed in two categories: prices of total steel products in exports and prices of total steel products in imports. The analysis was performed on the basis of statistical data provided by the Polish Steel Association in Katowice, Poland. This study is not intended to provide an in-depth market analysis of steel product prices, but only to locate steel product price fluctuations 
in a specific economic slowdown - the global financial crisis of 2008 and to present the situation - the Covid19 crisis.

\section{ANALYSIS OF PRICES OF STEEL PRODUCTS IMPORTED TO AND EXPORTED FROM POLAND IN THE PERIOD FROM 2005 TO 2020}

\subsection{Analysis of average annual price steel products of imported to and exported from Poland}

In the period from 2005 to 2020, the average price of steel products imported to Poland was higher than the average price of steel products exported by PLN 387 /tonne. The average annual price of imported steel products was PLN 3,091 /tonne, and for exports PLN 2,705 /tonne. Throughout the analyzed period, the average prices of imported steel products were higher than the prices of exported steel products, excluding prices of imported steel products in 2020 (annual price of imported steel products was PLN 3,157 /tonne, annual price of exported steel products was PLN 3,168/tonne). A detailed course of trends is presented in Figure 1.

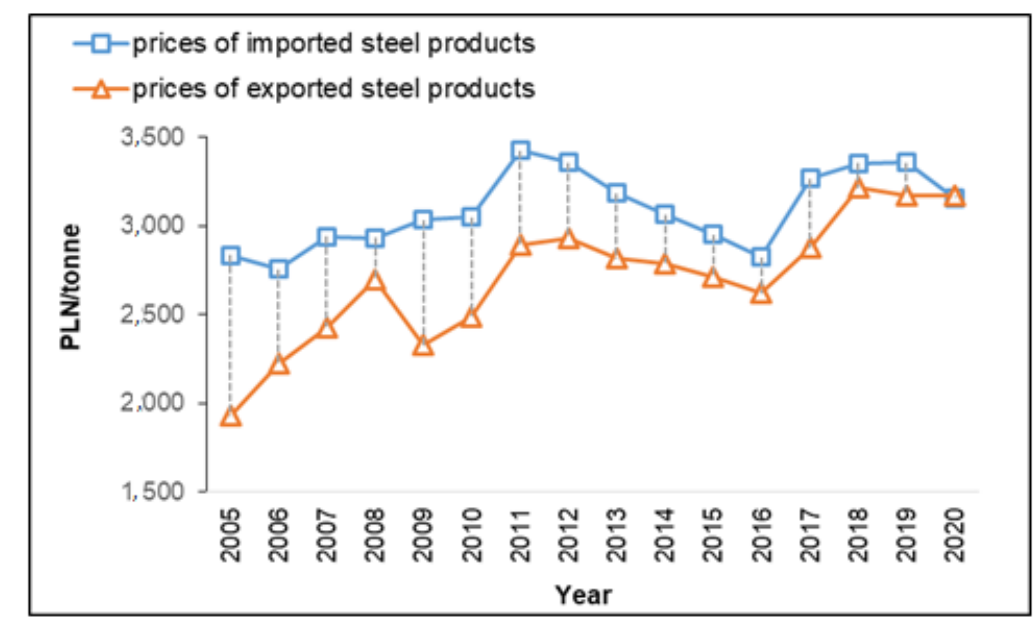

Figure 1 Average annual prices of steel products imported to and exported from Poland

Based on the analysis of trends (see Figure 1), one can notice that the price trends of imported and exported steel products after 2012 are getting closer. The differences between the prices of these steel products were smaller and smaller. In 2020, first time prices of steel products exported from Poland was higher than prices of steel products imported to Poland. Table 1 summarizes the data on the differences between the prices of imported and exported products based on the average annual prices of steel products in the period from 2005 to 2020 .

Table 1 Differences between the prices of steel products imported to and exported from Poland [PLN/tonne]

\begin{tabular}{|l|r|r|r|r|r|r|r|r|r|r|r|r|r|r|r|r|}
\hline Year & 2005 & 2006 & 2007 & 2008 & 2009 & 2010 & 2011 & 2012 & 2013 & 2014 & 2015 & 2016 & 2017 & 2018 & 2019 & 2020 \\
\hline Differences & 906 & 533 & 510 & 233 & 704 & 558 & 528 & 427 & 369 & 274 & 236 & 206 & 391 & 139 & 185 & -12 \\
\hline
\end{tabular}

\subsection{The impact of the crisis and the global economic slowdown on the prices of steel products imported to and exported from Poland}

During the global financial crisis, which begins with the American economy in 2008, the effects reach Poland in 2009, there are strong fluctuations in the prices of steel products imported to Poland and shipped abroad. Having the statistical data for the period from 2005 to 2020, an analysis of trends in prices of steel products in individual months of the year was performed. Steel product price trends are presented in Figure 2 and Figure 3. Looking at the steel product price trends, it can be seen that the price differences are greater. In 
2009, the price of exported products was lower by PLN 704 /tonne. A sharp drop was recorded during the crisis in the prices of steel products shipped abroad. In 2010, the difference amounted to PLN 558 /tonne and 2011, prices of exported products were lower by PLN 528 /tonne (see Table 1). The highest level of average prices for imported steel products was recorded in 2011, and for exported products in 2018. The maximum price of steel product imported to Poland was in October 2011 (PLN 3,800/tonne), and the minimum price was in March 2006 (2,503). Based on maximum and minimum of prices, three periods were analyzed: 2,500-3,000; $3,000-3,500 ; 3,500-3,800$. Since the emergence of the global economic crisis in Europe (since 2009), the prices of steel products imported to Poland have exceeded the amount of PLN 3,000 /tonne and more, excluding months (from January to November) in 2016 (see Figure 2).

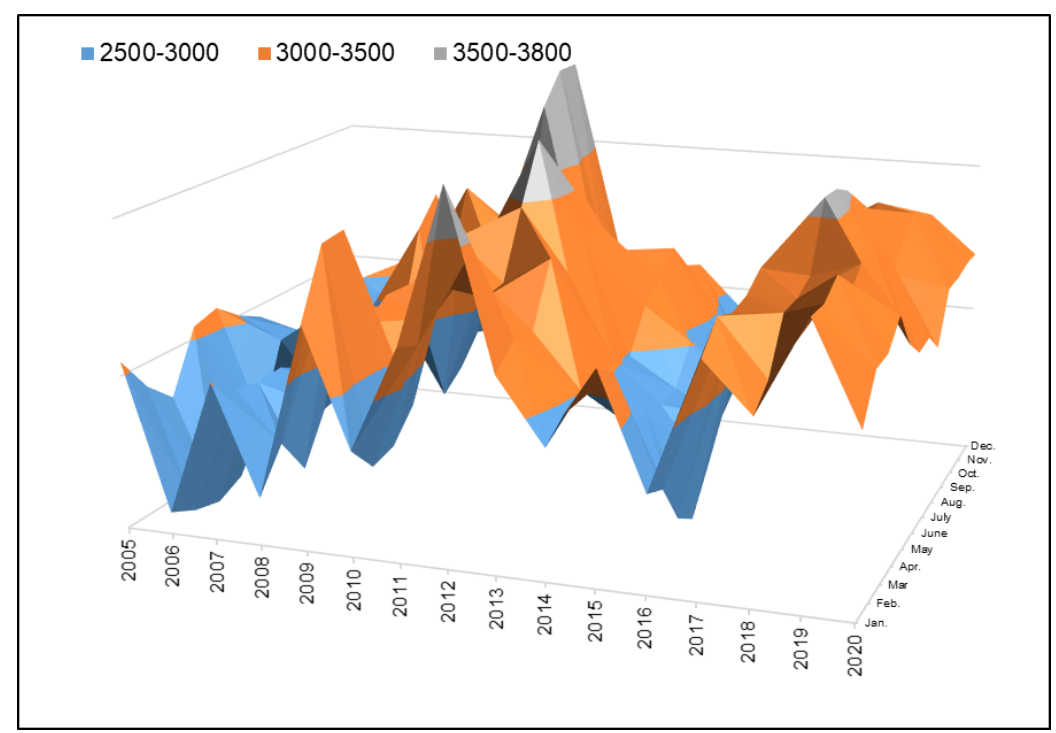

Figure 2 Prices band of steel products imported to Poland in the period from 2005 to 2020 [PLN/tonne]

Based on the analysis of price trends of imported steel products, strong fluctuations between prices were found until 2012 (see Figure 2). The high fluctuations in the first quarter and the beginning of the second were between 2006 prices (low prices in the period from January to April) and 2012 prices (very high prices in January). The high volatility in the third and fourth quarters was between 2005 prices (low August to December) and 2011 prices (high September to December). These strong price fluctuations were therefore in the run-up to and during the global financial crisis. The high prices recorded at the end of 2011 continued until July 2012 (in June 2019, 3,676 PLN was paid for 1 tonne of imported steel products). In the last four years before the pandemic year, prices soared, throughout 2017, throughout 2018 and throughout 2020, they were above 3,000 PLN /tonne (see Figure 2). In export, the price level above 3 thousand PLN/tonne of steel products was not recorded until 2018-2020, excluding December 2011 (PLN 3,002 /tonne), December 2012 (4,143) and November and December 2013 (3,015; 3,019) (see Figure 3). In 2012, a record price for exported steel products was recorded, in December, 4,143 PLN was paid per tonne of steel products. The lowest prices in individual months were in 2005 (in August, PLN 1,745/tonne of steel products). For analyzed prices, five periods were established: 1,700-2,200; 2,200-2,700; 2,700-3,200; 3,200-3,700 and 3,700-4,200.

In analysed period, the growth of prices of steel products exported from Poland was speed. The rationale for such large price increases is their greater added value and an increase in raw material prices. The price of steel has been high for ten years. The high price of steel is influenced by the high price of iron ore, energy, coke and environmental charges (carbon dioxide emission price). In the analyzed period, investment outlays amounted to about PLN 14 billion. The implemented investments allowed the steel mills to produce products of higher and higher standards and reduce energy consumption of resources [11-12]. Just before the pandemic 
(COVID-19), from February 2018 to November 2019, the prices of Polish export products remained slightly above PLN 3,000 /tonne of steel products, also in 2020, from March to December were above PLN 3,000 /tonne (see Figure 3).

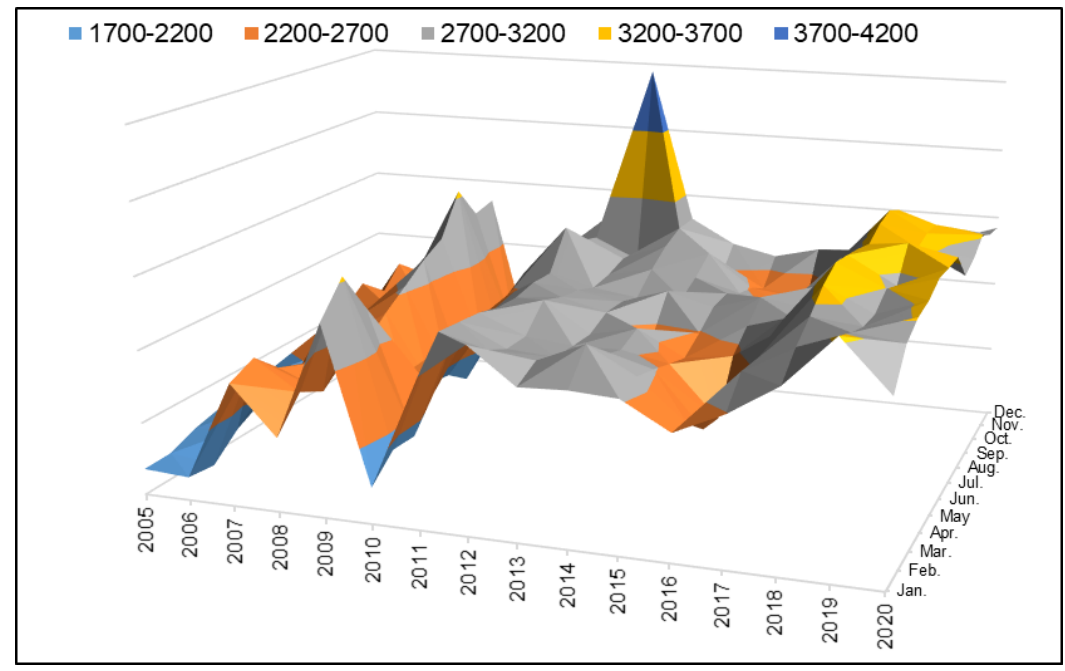

Figure 3 Prices band of steel products exported from Poland in the period from 2005 to 2020

[PLN/tonne]

\section{COVID'S PRICES EFFECTS - DISCUSSION}

2020 is known as the pandemic year. During the Covid-19 crisis, the Polish steel sector saw an increase in the prices of steel and steel products and strong fluctuations in the prices of exported and imported products. In 2020, the price of iron ore rose to USD 160 /tonne, the highest level since 2011. As late as November 2019, the price per tonne of iron ore was around USD 85 [13]. Steel scrap prices have also gone up. Apart from ore and scrap, high energy prices remain on the Polish steel market. The price of energy per 1 tonne of steel in Poland is higher than in other EU countries. When analysing the prices of annual electricity purchase contracts in Poland, Germany, Slovakia, the Czech Republic and Romania in 2015-2020, the prices on the Polish market significantly differ from our direct neighbours producing electricity [14], on average, in the analyzed period, prices in Poland were higher by $25 \%$ compared to Germany, $29 \%$ - the Czech Republic, $23 \%$ - Slovakia and $10 \%$ compared to Romania, and in the period from the beginning of 2019 , the average electricity price in Germany was lower from the price in Poland by nearly PLN $60 / \mathrm{MWh}$. The price difference is due to the fact that electricity in Poland is still produced from solid fossil fuels (over $77 \%$ in 2018). Over the years, electricity has been charged with many additional charges in Poland (e.g. the distribution fee, grid fee in 2020 was 41 /MWh of energy). According to Polish Steel Association, the level will be the same in 2021 [14]. The prices of steel and steel products will be strongly influenced by the carbon tax (a policy implemented by the European Union), which aims to include their carbon footprint in the prices of imported products. This is all the more important as the cost of carbon dioxide emissions in the $\mathrm{EU}$ is rising rapidly. Prices of $\mathrm{CO}_{2}$ emission allowances in January 2021 have already hit a record 34 EUR per tonne [15]. Rising costs of $\mathrm{CO}_{2}$ emissions, but also rising electricity prices and the introduction of additional fees within the capacity market from 2021, affect the prices on the steel market. In 2020, steel production in Poland was limited. Along with the decline in steel demand in the pandemic year, ArcelorMittal finally shut down the furnace for steel production in Krakow. Steel product price volatility in the Covid-19 crisis period is caused by lockdown. In the economies of the world, lockdown periods were shorter in some countries, longer in others, and not always at the same time. Postponing lockdowns had various effects, for example on the iron ore market, China emerged from the crisis earlier than other global iron ore suppliers. Increasing prices of raw materials needed to produce steel affect the prices of other products. The price of steel affects the final cost of producing cars, machines and other 
products, and thus their final price. The main recipient of steel products in Poland is the construction sector, so the prices of steel products will change prices in the construction industry (the boom in this industry is fostered by investments in the warehouse real estate sector - this is the effect of accelerating the development of e-commerce and the development of road infrastructure). Financial institutions and market experts predict that price increases in steel-consuming industries in Poland may be from $20 \%$ to even $50 \%$ depending on the steel grade [16]. After the first wave of pandemic period (which was already noted in Poland at the end of the fourth quarter of 2020, there was an increase in production), both the rapid rebound in demand and the effect of purchases on inventory will have an impact on the prices of exported steel products [17].

\section{CONCLUSION}

The analysis of the prices of imported and exported steel products for the Polish market may constitute the basis for in-depth analyzes, taking into account the costs of: raw materials, energy in Poland, as well as macroglobal situations. The Chinese economy and analysis of its recovery from the pandemic crisis may provide additional information. Mills in China are the largest steel producers in the world, as well as suppliers of the basic raw materials: iron ore, coking coal. The situation in this economy is an important element of forecasting price changes for imported steel products to Poland. In order to get a full picture of changes, one should also take into account the exchange rate of the euro against the zloty in the analyzed period. The analysis provides basic information about the fluctuations in prices of imported and exported steel products in the period from 2005 to 2019. The financial crisis (launched in USA 2008) and the downturn in the global economy in 2009 hit very hard in the price of steel products (strong fluctuations in imported and exported Poland of steel products) [18]. In the period, from 2005 to 2019, the prices of goods imported to Poland were higher than those of exported goods, but this difference has decreased in recent years and in 2020, average annual prices of steel products exported from Poland were higher than those of imported goods, but the difference was very low (for imported: PLN 3,157 /tonne and exported: PLN 3,168/tonne). 2020 was a pandemic year with further disruptions on the steel market in Poland, e.g. high prices of materials, energy, and high cost of environmental protection. The speed of recovery from the crisis, not only by market factors, e.g. prices of goods and demand for steel), but also by govermental support instruments (aid programs for the steel sector) and EU policy in Covid-19 crisis.

\section{ACKNOWLEDGEMENTS}

\section{Silesian University of Technology (Faculty of Materials Engineering), supported this work as a part of Statutory Research 11/040/BK_21/0023}

\section{REFERENCES}

[1] BUNDY, J., PFARRER, M.D., SHORT, C.E., COOMBS, W.T. Crises and Crisis Management: Integration, Interpretation, and Research Development. Journal Manag. 2017, vol. 43, pp. 1661-1692. Available from: https://doi.org./10.1177/0149206316680030

[2] TANEJA, S., PRYOR, M.G., SEWELL, S., RECUERO, A.M. Strategic crisis management: A basis for Reneval and crisis Prevention. Journal Manag. Policy Pract. 2014, vol. 15, pp. 78-85.

[3] WISMAN, J.D. Wage stagnation, rising inequality and the financial crisis of 2008. Camb. J. Econ. 2013, vol. 37, pp. 921-945.

[4] World Steel in Figures 2020. Chapter: World crude steel production, 1950 to 2019. World Steel Association, pp. 6-7.

[5] Steel Statistical Yearbook 2010. World Steel Association. Available from: https://www.worldsteel.org/steel-bytopic/statistics/steel-statistical-yearbook.html.

[6] Global steel industry overview. World Steel Association. December 2020 (data to Oct., and plus data from Nov. and Dec.) 
[7] WorldSteel Association, Statistics. Available from: https://www.worldsteel.org/moreitems.html?tag=\%2Fstatistics\&page= 1 \&origin=\%2Fzh\%2Fmedia-centre\%2Fblog.html.

[8] European Steel in Figures 2020 Axel Eggert, Director General The European Steel Association (EUROFER). Available from: https://www.eurofer.eu/assets/Uploads/European-Steel-in-Figures-2020.pdf.

[9] Trading Economics: European Union Steel Production 1990-2020 Data. Available from: https://tradingeconomics.com/european-union/steel-production: based on World Steel Association

[10] Polish Steel Industry (unpublished data). Polish Steel Association. Katowice. Poland. 2020.

[11] GAJDZIK, B., SROKA, W. Resource Intensity vs. Investment in Production Installations - The Case of the Steel Industry in Poland. Energies. 2021, vol. 14, 443. Available from: https://doi.org/10.3390/en14020443.

[12] WOLNIAK, R., SANIUK, S., GRABOWSKA, S., GAJDZIK, B. Identification of Energy Efficiency Trends in the Context of the Development of Industry 4.0 Using the Polish Steel Sector as an Example. Energies, 2020, vol. 13, 2867. Available from: https://doi.org/10.3390/en13112867.

[13] Zespół 300Gospodarki 11 Jan. 2021, Available from: https://300gospodarka.pl/explainer/stal-jest-dzis-najdrozszaod-niemal-10-lat-tlumaczymy-co-to-oznacza-i-dlaczego-to-wazne.

[14] DZIENNIAK, S. ZAGÓRSKA, M. Droga energia przyczyną niskiej konkurencyjności polskiej gospodarki na przykładzie przemysłu stalowego. PTE 2020. The prepared content was presented at the conference "Economic effects of the pandemic" organized by PTE (Katowice, 22 September 2020).

[15] OKSIŃSKA, B. Widoczna już teraz odbudowa popytu i eksplozja cen wyrobów hutniczych dają nadzieję na istotną poprawę sytuacji branży stalowej. Serwis Rzeczpospolitej. [vieiwed:2021-01-17, 20:11] Available from:https://www.rp.pl/Hutnictwo/301179932-Wraz-z-ozywieniem-w-przemysle-na-rynek-stali-wracaoptymizm.html.

[16] Brokerage House BDM SA. Analysis of GPW and experts opinions of GPW, [viewed: 2021-02-10]. Available from https://www.fxmag.pl/artykul/notowania-gieldowe-ceny-stali-zblizaja-sie-do-rekordowych-1000-eurt-ok-150-procwzrost-od-dolka-z-sierpnia-kto-produkuje-i-dystrybuuje-stal-na-gpw.

[17] Stock quotes [viewed: 2021-02-12]. Available from: https://www.fxmag.pl/artykul/notowania-gieldowe-ceny-stalizblizaja-sie-do-rekordowych-1000-eurt-ok-150-proc-wzrost-od-dolka-z-sierpnia-kto-produkuje-i-dystrybuuje-stalna-gpw.

[18] GAJDZIK, B., WOLNIAK, R. Influence of the COVID-19 Crisis on Steel Production in Poland Compared to the Financial Crisis of 2009 and to Boom Periods in the Market. Resources. 2021, vol. 10, no. 1, pp. 1-17. 